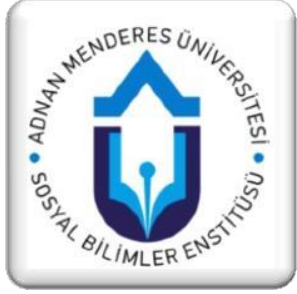

Makale Gecmisi

Başvuru Tarihi:20.04.2021

Kabul Tarihi:15.06.2021

\section{Kamu Çalışanlarının Sanal Kaytarma Davranışları ve Kişilik Özellikleri İlişkisi: Aydın Adliyesi Örneği}

\author{
Halim Emre ZEREN ${ }^{1}$, Nilay YALÇIN ${ }^{2}$
}

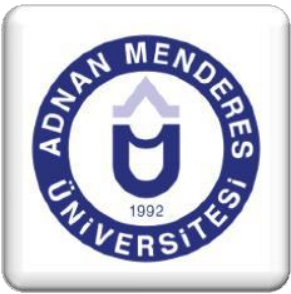

Article History

Date of Application:20.04.2021

Acceptance Date:15.06.2021

\title{
Özet
}

Bu çalışma, kamu kurumu çalışanlarının sanal kaytarma olarak ifade edilen mesai saatleri içerisindeki iş dışı eylemleri (müzik dinleme, oyun oynama, online alışveriş, vd.) ile demografik özellikleri arasındaki ilişkinin analiz edilmesi amacıyla yapılmıştır. Bu bağlamda çalışmanın örneklemi, Aydın Adliyesi'nde görev yapan 105 kamu çalışanından oluşmaktadır. Araştırma verileri anket yöntemi ile toplanmıştır. Araştırmada, önemli sanal kaytarma davranışları ve önemsiz sanal kaytarma davranışlarını ifadelerini temsil eden Balanchard ve Henle (2008) "Sanal Kaytarma Ölçeği” kullanılmıştır. Ölçekte yer alan ifadelere güvenilirlik analizi ve faktör analizi uygulanmıştır. Verilerin, Shapiro-Wilk testi sonucunda normal dağılım göstermediği tespit edilmiştir. Veriler normal dağılım göstermediği için cinsiyet ve medeni durum değişkenleri Mann-Whitney U Testi ile; yaş, eğitim, görev yılı ve konum değişkenleri ise Kruskal Wallis H Testi ile ölçülmüștür. SPPS 25.0 programı ile analiz edilen veriler sonucunda, Aydın Adliyesi'nde görev yapan kamu çalışanların sanal kaytarma davranışları ile medeni durum ve cinsiyet arasında anlamlı bir ilişki olmadığı; yaş, cinsiyet, görev yılı ve konum arasında ise anlamlı bir ilişki olduğu tespit edilmiştir.

Anahtar Kelime: Kamu Kurumu, Sanal Kaytarma, Demografik Özellikler, Aydın

Jel Kodları: J24, J28, J29

\section{The Relationship Between Cyber Loafing Behaviors and Personality Traits of Public Employees: Example of Aydın Courthouse}

\begin{abstract}
This study was conducted to analyze the relationship between the demographic characteristics of public institution employees' out-of-work activities (listening to music, playing games, online shopping, etc.) during working hours, which are expressed as cyber-loafing. In this context, the sample of the study consists of 105 public employees working in Aydin Courthouse. The research data were collected by the survey method. Balanchard and Henle (2008) "Cyber Loafing Scale", which represents important cyber-loafing behaviors and trivial cyber-loafing behaviors, was used in the study. Reliability analysis and factor analysis were applied to the statements in the scale. It was determined that the data did not show a normal distribution due to the ShapiroWilk test. Since the data did not show a normal distribution, gender and marital status variables were analyzed using the Mann-Whitney U Test; Age, education, years of duty and location variables were measured with Kruskal Wallis H Test. As a result of the data analyzed with the SPPS 25.0 program, it was found that there was no significant relationship between cyber-loafing behaviors of public employees working in Aydin Courthouse and marital status and gender; It has been determined that there is a significant relationship between age, gender, year of duty and position.
\end{abstract}

Keywords: State Agency, Cyber Loafing, Demographic Features, Aydın

Jel Codes: J24, J28, J29

\footnotetext{
${ }^{1}$ Doç. Dr., Adnan Menderes Üniversitesi Söke İşletme Fakültesi Kamu Yönetimi, emre.zeren@adu.edu.tr, ORCID ID: 0000-0002-8681-2397

${ }^{2}$ Yüksek Lisans Öğrencisi, Adnan Menderes Üniversitesi Söke İşletme Fakültesi İnsan Kaynakları Yönetimi, nilayyalcin09@gmail.com, ORCID ID: 0000-0003-0608-3524
} 


\section{Giris}

Dünyanın küresel bir köy haline gelmesi ve bilgi çağını yaşamasıyla beraber artan rekabet sonucunda işletmeler teknolojik gelişmeleri yakından takip etmeye başlamışlardır. $\mathrm{Bu}$ yeniliklerden en önemlisi olarak görülen internet, iş hayatında ve sosyal hayatta önemli bir yer edinmiş̧ir. Tüm işletmelerde işlerin internet üzerinden yapılması; zaman tasarrufu, maliyet kıstı, iletişim olanakları, bilgiye kolay ve hızlı ulaşım gibi olanakları beraberinde getirmiştir. Hizmet yoğun bir sektör olan kamu kuruluşlarının bilgi sistemleri ile entegre edilmesi, çalışanların iş yükünü azaltmıştır. Kamu kurumlarında bağlı olan internetin kısıtlı erişim sağlaması, kablosuz internetlerin gelişim sürecine kadar olumlu katkılar sağlamıştır. Ancak kablosuz internet ağlarının gelişimi ile beraber artan kişisel internet ve cep telefonu kullanımı, çalışanları olumlu ve olumsuz yönde etkilemektedir.

TÜİK 2007-2020 yılları arasındaki verilere göre "kişisel amaçla kamu kurum/kuruluşlarında internet kullananların oranı"; 2007 yılında \%7,2 olarak ifade edilmektedir. Bu oranın 2011 y1lında \%16,8'e, 2015 y1lında \%28,4'e ve 2020 y1lında \%51,5'e yükseldiği görülmektedir. $\mathrm{Bu}$ oranların kadın ve erkekler arasındaki dağılımına bakıldığında; 2007 yılında kadınların kişisel amaçlarla kamu kurumlarında internet kullanım oranı \%4,2, 2011 yılında \%11,9, 2015 yilında \%21,6 ve 2020 y1lında \%41,1 olarak tespit edilmiştir. Erkeklerde bu oranın 2007 y1lında \%10,0, 2011 y1lında \%21,7, 2015 y1lında \%35,3 ve 2020 y1lında $\% 62,1$ olduğu görülmektedir (TÜİK, 2020).

Çalışan kişilerin mesai saatleri içinde, haber sitelerini ziyaret etmeleri, alışveriş yapmaları, iş dışı mailleri okumaları, sosyal ağ uygulamalarını kullanmaları kısaca, iş dışı faaliyetlerde bulunmalarını açıklayan sanal kaytarma, özellikle kablosuz internetin gelişimi ile iş yerinde oluşan olumsuz bir durumu anlatmaktadır. Çalışanların sanal kaytarma davranışlarına başvurması sadece olumsuz olarak algılanmamalı, çalışanların bu olanakları ne amaçla kullandığı değerlendirilmelidir (Özkalp ve Yıldız, 2018: 59). Çalışanların ne amaçla sanal kaytarma davranışlarına başvurmasının yanında kimlerin sanal kaytarmaya davranışlarına başvurduğu, işletmelerin alacağı önlemler açısından öncelik teşkil etmelidir. Yöneticiler işletmelerin verimlilik düzeyini artırmak için, çalışanların kişisel amaçları ile örgütsel amaçları ile bir bütünlük sağlamalıdır (Kaplan ve Çetinkaya, 2014: 27). Bunun için yöneticilerin; hangi yaş grubuna, eğitim düzeyine veya cinsiyetine mensup çalışanların hangi davranışları gösterdiğini bilmeleri önem arz etmektedir.

$\mathrm{Bu}$ amaçla, çalışanların demografik özellikleri ile sanal kaytarma davranışları arasındaki ilişkinin incelenmesini konu olan çalışma; kavramsal çerçeve, araştırma, bulgular ve sonuç bölümlerinden oluşmaktadır.

\section{Sanal Kaytarma}

Sanal kaytarma kavramı, uluslararası alanda Robinson ve Bennett (1995)'in çalışmasını temel alan Lim (2002) tarafından literatüre kazandırılırken, Türkçe kaynaklarda ise ilk kez Özkalp, Aydın ve Tekeli (2012) gibi araştırmacılar tarafından yapılan çalışmalarda kullanılmaya başlanmıştır (Seçkin ve Kerse, 2017: 88). Uluslararası literatürde "Virtual Slacking, Cyberslacking, Personel Web Usage, Cyberloafing" gibi çeşitli ifadelerle kullanılan sanal kaytarma, Türkçe çalışmalarda "Siber Aylaklık, Sanal Aylaklık, Siber Kaytarma, Sanal Kaytarma" olarak da kullanılmaktadır (Özüdoğru ve Yıldırım, 2020: 468). Sanal kaytarma kavramını Lim (2002), "Çalışanların mesai saatleri içinde iş amaçlı kullanılması istenen bilgisayar ve internetin kişisel amaçlar doğrultusunda kullanılması" olarak tanımlamıştır (Kerse ve Soyalın, 2018: 212). Ancak kişisel cep telefonu kullanımın artması ile gelişen kablosuz internet hizmeti ve işletme internet ağına konulan kısıtlamalardan dolayı, sanal kaytarma başka bir boyuta ulaşmıştır. Günümüzde sanal 
kaytarma kavramı, çalışanın iș saatleri içerisinde kişisel veya örgütsel cihazlarını kendi özel amaçları doğrultusunda kullanması olarak ifade edilmektedir (Ünal ve Tekdemir, 2015: 97; Çavuşoğlu ve Palamutçuoğlu, 2017: 432). Öte yandan günümüzde sanal kaytarmanın örgütsel cihazların kullanımından ziyade çalışanın zamanını işi için harcamaktan kaçınması ve işte geçirdiği zamanda zihnen özel hayatını yaşamaya devam etmesi şeklinde algılandığı ifade edilebilir.

Personelin mesai saatleri içinde kişisel amaçlı mail alma ve gönderme, video izleme, oyun oynama, sosyal medya hesaplarını kontrol etme, bankacılık işlemleri yapma, haber sitelerini ziyaret etme, online alışveriş yapma gibi çeşitli işlemleri gerçekleştirmeleri sanal kaytarma olarak ifade edilmektedir (Arslan ve Demir, 2016: 1627). Sanal kaytarma davranışları olarak sıralanan bu faaliyetlerle ilgili literatürde farklı sinıflandırmalara rastlanmaktadır. Sanal kaytarma davranışlarını Anandarajan, Devine ve Simmers (2004), bireysel verimliliğe zarar verici, yaratıcı ve öğretici sanal kaytarma davranışları olmak üzere üç boyutta incelemişlerdir. Lim (2002), internet sitesi etkinlikleri ve e-posta etkinlikleri olarak gruplandırırken Blau, Yang ve Ward-Cook (2006) ise Lim (2002)'in gruplandirmasina benzer olarak internet sitesi ile ilgili faaliyetler, kişisel amaçlı e-posta faaliyetleri ve etkileşimli sanal kaytarma faaliyetleri olmak üzere üç gruba ayırmışlardır (Kaplan ve Öğüt, 2012: 4). Son olarak, Robinson ve Benett (1995) ile Balanchard ve Henle (2008) önemli ve önemsiz siber kaytarma davranışları olarak iki boyutta değerlendirmişlerdir (Buyruk Akbaba, 2018: 164; Özdem ve Demir, 2015: 1031). Araştırmada esas alınan bu sınıflandırmadan önemsiz sanal kaytarma davranışları, yapılması normal karşılanan ve bireyin iş yoğunluğundan uzaklaşmasını sağlayan "iş dışı e-posta atma veya cevap verme, haber sitelerini ziyaret etme, internet bankacılığı işlemleri yapma" gibi davranışları içermektedir. Önemli sanal kaytarma davranışları ise, uzun süreli, işletme ve bireysel verimliliği düşürücü etki gösteren ve sonucunda yaptırımları olması olası olan "kişisel web sayfasını düzenleme, yetişkin odaklı siteleri ziyaret etme, sanal topluluklara katılma, online alışveriş yapma" gibi davranışlardan oluşmaktadır (Küçük ve Nur, 2019: 1104).

Çalışanların sanal kaytarma davranışlarının görülmesinde sadece örgütsel nedenlerin değil, kişisel nedenlerin de etkisi olduğu görülmektedir. Bu bazen internet bağımlılığı, gibi çözülmesi zor bir neden olurken, bazen de o günün stresine bağlı küçük bir sorundan kaynaklanmaktadır. Sanal kaytarma nedenlerini Van Doorn (2011) üç gruba ayırmıştır (Akt. Örücü ve Özüdoğru, 2018: 68-69):

- Örgüt ile İlgili Nedenler: Personelin sanal kaytarma davranışları, kurum tarafindan oluşturulan internet ağı politikaları ile düzenlenmektedir. Özellikle kamu kurumlarında sağlanan sınırlı erişim hakkı en azından işletme bilgisayarı ve ağını kullanmasını engellemektedir. Böylece, işletmeye ait internet yavaşlama sorunu ve sistem ağına yönelik bir virüs tehdidi ortadan kalkmaktadır. Ancak günümüzde gelișen teknoloji ile ișletmenin aldığı bu tedbirler yetersiz kalmaktadır. Bu durumun sadece işletmenin maruz kalacağı olumsuz durumları azaltmaktadır.

- İş ile İlgili Nedenler: İş talebinin yoğun veya az olduğu zamanlarda, işten kaçmak veya dinlenmek amacıyla sanal kaytarma davranışları artırıcı etki gösterirken, denge durumunda ise azalmaktadır. Çalışanın işletmede yer aldığı pozisyon da burada etkili olmaktadır. Örneğin; bir kamu kurumunda vatandaşlar ile yüz yüze hizmet veren bir görevli sanal kaytarma davranışlarını az sergilerken, işinde daha rahat, vatandaşlar ile yüz yüze iletişimi olmayan olan bir çalışan sanal kaytarma davranışlarına daha sık başvurabilmektedir. Ayrıca sanal kaytarma davranışları, işin yoğun veya azlığından ziyade, çalışanın mobbinge maruz kalması, örgütsel adaletin eksik olduğunu hissetmesi ve takdir edilmemesi, stres ortamının 
varlı̆̆ı, işletmede düşük ücret politikaların uygulanması gibi iş ile ilgili yaşanan sorunlardan da kaynaklanabilir.

- Kişilik Özellikleri: Kişilerin günlük hayatta yaşadığı sorunlar sanal kaytarma davranışlarına etki etmektedir. Bunlardan en önemlisi olan internet bağımlığı, kişinin günlük hayatta yaşadığ 1 sorunlar, nevrotik bozukluğa sahip olma gibi nedenler sanal kaytarma davranışlarını etkilemektedir.

Buradaki ayrıma mobil teknolojilerin yaşam tarzı haline gelmesi şeklinde bir ekleme yapmak da mümkündür. Sosyal paylaşım siteleri, günümüzde insanların neredeyse tamamının sahip olduğu, hayatın önemli bir parçası durumuna gelmiş olan uygulamalardır. Bu uygulamalarla yaşamanın insanlar için kanıksanan bir durum olduğu ifade edilebilir.

Mesai saatleri içinde yürütülen sanal kaytarma davranışlarının, çalışanlar ve işletme açısından olumlu ve olumsuz sonuçlar doğurduğu söylenebilir. Önemli sanal kaytarma davranışları, suiistimale açık eylemlerdir ve hem çalışan hem de işletme açısından zararları bulunmaktadır. Çalışan açısından verimliliği ve üretkenliği azaltıcı etki ederken, aynı zamanda itibarını tehlikeye düşürmektedir (Ünal ve Tekdemir, 2015: 99). Normal şartlarda zaten iş ile ilgili aksatma eylemlerinde bulunan çalışanın iş arkadaşları arasında da soyutlanmasının örgütsel bağl1lı̆̆ azalacağı söylenebilir. $\mathrm{Bu}$ durumun örgüt açısından maliyet kayıplarına, verimsizliğe ve üretimin azalmasına yol açacağı öngörülmektedir. Ayrıca bu tür eylemlerin işletme ağından yapılması sonucunda, işletme ağı siber saldırılara maruz kalabilir. Özellikle kamu kurumlarında vatandaşların bilgilerine erişilmesi sonucunda kişisel verilerin ihlali gibi ciddi sorunlara yol açabilmekte ve işletmeler yasal yaptırımlarla karşı karşıya kalabilir (Karatepe ve Güngör, 2017: 84).

Önemsiz ve kısa süreli olan sanal kaytarma davranışlarının çalışanların yetenek ve becerilerini artırarak, bilgiye hızlı ulaşım sağlaması açısından örgüt ve bireysel verimliliğe katk1 sağladığ1 düşünülmektedir (Karataş ve Avci, 2017: 2325). Kişinin iş ile ilgili eğitici videolar izleyerek yeteneklerini ön plana çıkarması, odaklanması gereken bir işten başlamadan önce internette gezinerek kısa bir mola vermesi sanal kaytarma davranışlarının olumlu sonuçları arasında gösterilebilir. Sonuç olarak, sanal kaytarma davranışları çalışanlara kısa vadede bilgi ve becerilerini artırmaya yönelik etki ederken, uzun dönemde örgüt üretimini ve kişisel verimliliği azaltarak işletmenin maliyetlerini düşürebilir. Bu da astüst ilişkilerinin bozulmasına yol açabilir ve böylece çalışanın örgütsel bağgının azalması söz konusu olabilir (Kerse ve Soyalın, 2018: 212).

\section{Sanal Kaytarma ve Demografik Özellikler Arasındaki İlișki}

Sanal kaytarma davranışları örgütsel ve kişisel özelliklerden kaynaklı nedenler ile yapılmaktadır. Yöneticilerin, çalışanların sanal kaytarma davranışlarını engellemek için neden yapıldığını araştırdıktan sonra, sıra kimlerin sanal kaytarma davranışları gösterdiğini tespit etmesi gerekmektedir. Böylece kurumda buna yönelik politikalar oluşturulabilir. $\mathrm{Bu}$ amaçla, sanal kaytarma davranışları ile demografik özellikler arasındaki ilişkinin incelenmesi yararlı olacaktır. Literatürde sanal kaytarma davranışları ve demografik özellikler arasındaki ilişki incelendiğinde; Örücü ve Yıldız (2014) Balıkesir Üniversitesi’nde görev yapan akademik ve idari personel ile yaptıkları araştırmada, sanal kaytarma davranışları açısından çalışanların cinsiyet değişkenine göre istatiksel olarak belirleyici bir farklılık olmadığı ancak çalışanların medeni durum, yaş, eğitim değişkenleri arasında istatiksel olarak belirleyici farkl1lıklar olduğu tespit edilmiştir. Ünal, Tekdemir ve Yaldızbaş (2015) Antalya Bölge Müdürlüğü'nde görev yapan kamu çalışanları üzerine yaptıkları araştırmada, olumlu ve olumsuz siber kaytarma davranışlarıyla çalışanların cinsiyet değişkeni arasında istatiksel olarak belirleyici bir farklılık bulunmadığını; buna karşın 
çalışanların yaş, eğitim durumu ve işletmedeki konumları gibi değişkenlerle (yönetici veya memur) işletmedeki görev süresi değişkeni arasında istatiksel olarak belirleyici bir farklılık olduğunu ortaya koymuşlardır. Arslan ve Demir (2016), bir kamu hastanesinde görev yapan hemşireler üzerinde yaptıkları araştırmada çalışanların cinsiyet değişkeni ile sanal kaytarma davranışları arasında belirleyici bir farklılık olmadığını belirtirken; farklılığın çalışanların medeni durum, yaş, işletmedeki görev süresi gibi değişkenleri arasında belirleyici olduğunu ifade etmiş̧lerdir. Çınar ve Siçrar (2019), Erzurum Kara Yolları 12. Bölge Müdürlüğü’nde çalışan kamu görevlileri üzerine yaptıkları araştırmada, sanal kaytarma davranışları ile kurumda görev yapan memurların eğitim, yaş, cinsiyet, medeni durum değişkenleri açısından ilișkinin belirleyici olduğu bulgusuna ulaşılmıştır. Küçük ve Nur (2019) bir devlet üniversitesinde çalışan akademik ve idari personel ile yaptıkları araştırmada, çalışanların sanal kaytarma davranışları ile cinsiyet değişkeni arasında istatiksel olarak belirleyici bir farklı1ık olmadığını ancak medeni durum, yaş ve eğitim değişkeni arasında belirleyici bir farklılık gösterdiğini ortaya koymuşlardır. Bu çalışmaların sonuçlarından da hareketle; kamu kurumunda çalışanların sanal kaytarma davranışları ile demografik özellikleri arasındaki ilişkiler incelendiğinde şu hipotezler belirlenmiştir:

$\mathbf{H}_{1}$ : Sanal kaytarma davranışları ve cinsiyet değişkeni arasında belirleyici bir farklılık vardır.

$\mathbf{H}_{2}$ : Sanal kaytarma davranışları ve yaş değişkeni arasında belirleyici bir farklılık vardır.

$\mathbf{H}_{3}$ : Sanal kaytarma davranışları ve medeni durum değişkeni arasında belirleyici bir farklılık vardir.

$\mathbf{H}_{4}$ : Sanal kaytarma davranışları ve eğitim değişkeni arasında belirleyici bir farklılık vardır.

H$_{5}$ : Sanal kaytarma davranışları ve görev süresi değişkeni arasında belirleyici bir farklılık vardir.

$\mathbf{H}_{6}$ : Sanal kaytarma davranışları ve işletmedeki konum değişkeni arasında belirleyici bir farkl11ık vardir.

\section{Araştırma}

Çalışmanın bu bölümünde araştırmanın amacına, kapsam ve yöntemine ilişkin bilgilere yer verilerek çalışmaya ilişkin bulgular paylaşılmıştır.

\subsection{Araştırmanın Amacı, Kapsamı ve Yöntemi}

Araştırma, kamu kurumu çalışanlarının sanal kaytarma davranışları ile demografik özellikleri arasındaki ilişkiyi analiz etmeyi amaçlamaktadır. Bu nedenle araştırmanın örneklemi, bir kamu kurumu olan Aydın Adliyesi'nin çalışanlarından oluşmaktadır. Araştırmada verilerini toplayabilmek için anket yöntemi tercih edilmiştir. Oluşturulan anket, "Google Formlar" programı tarafından çalışanların mesai saati dışında maillerine ve cep telefonlarına gönderilmiştir. $\mathrm{Bu}$ yöntem ile araştırmanın verileri, olasılıklı olmayan örnekleme yöntemlerinden kolayda örnekleme ile toplanmıştır. Anket, 27/10/20-07/11/2020 tarihleri arasında, çalışanların erişimine açık bırakılmıştır ve 105 kişi tarafından doldurulmuştur.

Çalışmanın etik kurul uygunluk onayı, Adnan Menderes Üniversitesi Rektörlüğ̈̈ Sosyal ve Beşeri Bilimler Araştırmaları Etik Kurulu'nun 26.05.2021 tarihinde yapılan ve 31906847/050.04.04-08 sayılı olağan toplantısında "Etik Kurul Uygunluk Onayı" almasına oy birliği ile karar verilmiştir.

Günümüzde yaşanan COVID-19 pandemi sürecinden dolayı araştırma, nicel çalışma ve kısıtlı sayıda çalışan ile sınırlı kalmıştır. Araştırma anketi, yüz yüze görüşme olmadığından 
dolayı üst kademedeki görevlilere (başsavcı, savcı, hâkim vb.) ulaştırılamamıştır. Çalıșma genellikle sanal kaytarma davranışları göstermeye yatkın olan, masa başı çalışanlardan alınan veriler ile oluşturulmuştur.

Çalışanların sanal kaytarma davranışları, Balanchard ve Henle (2008) tarafindan geliştirilen, Kaplan ve Ögüt (2012) tarafından Türkçeye uyarlanan "Sanal Kaytarma Davranışları Ölçeği” kullanılarak ölçülmüştür. Ölçek, önemli sanal kaytarma ve önemsiz sanal kaytarma davranışları olmak üzere 17 ifadeden oluşmaktadır. Ankette, 5'li Likert ölçeği (hiçbir zaman1, nadiren-2, zaman zaman-3, sıklıkla-4, çok sık-5) kullanılmıştır. Toplanan veriler, SPSS 25.0 istatistik programı ile analiz edilmiştir. Ölçekte yer alan ifadelere güvenilirlik analizi yapılmıştır ve Cronbach's Alpha değeri 0,830 olarak tespit edilmiştir.

Tablo 1. Sanal Kaytarma Ölçeği Güvenilirlik Analizi

\begin{tabular}{|l|l|}
\hline Cronbach's Alpha & Madde Sayısı \\
\hline, 830 & 17 \\
\hline
\end{tabular}

Araştırmada ölçeğe faktör analizi uygulanmıştır. Ölçeğin faktör analizine uygun olduğunu belirleyen "KMO değeri" 0,767 ve "Bartlett Küresellik Testi" Signifiance = 0,000 olduğu için $(p<0,05)$ faktör analizi yapmaya uygun olduğuna karar verilmiştir (Küçük ve Nur, 2019: 1108).

Tablo 2. Sanal Kaytarma Ölçeğinin KMO ve Bartlett's Testi

\begin{tabular}{|l|l|}
\hline KMO & Değer \\
\hline Bartlett's Testi &, 767 \\
\hline Yaklaşık Ki-Kare & 703,441 \\
\hline df & 136 \\
\hline Sig. &, 000 \\
\hline
\end{tabular}

Verilerin normal dağılıp dağılmadığını analiz etmek için, "Shapiro-Wilk" Testi yapılmıştır. Analiz sonucunda verilerin normal dağılım göstermediği $($ Sig. $=, 000)$ belirlenmiştir. Bunun için araştırmada iki grup içeren ve parametrik olmayan değişkenler (cinsiyet, medeni durum) için "Mann-Whitney U Testi"; ikiden fazla grup içeren ve parametrik olmayan değişkenler (eğitim durumu, yaş, görev süresi ve konum) için "Kruskal Wallis H Testi” uygulanmıştır.

\section{Bulgular}

\subsection{Demografik Özellikler ile İlgili Bulgular}

Araştırmaya katılan çalışanların demografik özellikleri incelendiğinde (Tablo 3), ankete katılan çalışanların \%66,7'sinin kadın, \%33,3'ünün erkek; \%1'inin ilköğretim \%54,3'ünün lisans mezunu, \%74,3'ünün evli, \%25,7'sinin bekar; \%3,8'inin 18-25, \%33,3'ünün 34-41 yaş aralı̆̆ında; \%6,7'sinin hâkim-savı, \%69,5'inin memur; \%13,3'ünün 16-20 yıl, \%23,8'inin 11-15 yıl arasında hizmet süresi olduğu görülmektedir.

Araştırmaya katılan çalışanların demografik özellikleri, katılımcıların özelliklerine bakıldığında, çoğunlukla kadın, lisans mezunu ve memur statüsünde çalışanlardan oluştuğu görülmektedir. Ayrıca araştırmaya katılan çalışanların yaş değişkeni olarak, \%33,3'lük kısmının internet ve bilgisayar ile büyüyen Y Kuşağına ait çalışanlardan oluşmaktadır. 
Tablo 3. Ankete Katılanların Demografik Özellikleri

\begin{tabular}{|c|c|c|c|c|c|c|c|}
\hline-5 & 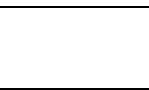 & $\begin{array}{c}\text { Sayı } \\
\text { (n) }\end{array}$ & $\begin{array}{c}\text { Oran } \\
(\%)\end{array}$ & & & $\begin{array}{c}\text { Sayı } \\
\text { (n) }\end{array}$ & $\begin{array}{c}\text { Oran } \\
(\%)\end{array}$ \\
\hline \multirow{2}{*}{ Cinsiyet } & Kadın & 70 & $\% 66,7$ & \multirow[t]{2}{*}{ Medeni Durum } & Evli & 78 & $\% 74,3$ \\
\hline & Erkek & 35 & $\% 33,3$ & & Bekar & 27 & $\% 25,7$ \\
\hline Toplam & & 105 & $\% 100$ & Toplam & & 105 & $\% 100$ \\
\hline \multirow{5}{*}{ Yaş } & $18-25$ & 4 & $\% 3,8$ & \multirow{5}{*}{ Eğitim Durumu } & İlköğretim & 1 & $\% 1,0$ \\
\hline & $26-33$ & 25 & $\% 23,8$ & & Ortaöğretim & 14 & $\% 13,3$ \\
\hline & $34-41$ & 35 & $\% 33,3$ & & Ön Lisans & 27 & $\% 25,7$ \\
\hline & $42-49$ & 28 & $\% 26,7$ & & Lisans & 57 & $\% 54,3$ \\
\hline & $50+$ & 13 & $\% 12,4$ & & Yüksek Lisans & 6 & $\% 5,7$ \\
\hline Toplam & & 105 & $\% 100$ & Toplam & & 105 & $\% 100$ \\
\hline \multirow{5}{*}{ Görev Süresi } & $1-5 Y_{11}$ & 22 & $\% 21,0$ & \multirow{5}{*}{$\begin{array}{l}\text { Konum } \\
\text { / Unvan }\end{array}$} & Hâkim-Savcı & 7 & $\% 6,7$ \\
\hline & 6-10 Y1l & 20 & $\% 19,0$ & & Müdür-Md. Yrd. & 11 & $\% 10,5$ \\
\hline & $11-15 Y_{11}$ & 25 & $\% 23,8$ & & Memur & 73 & $\% 69,5$ \\
\hline & $16-20 Y_{11}$ & 14 & $\% 13,3$ & & Diğer & 14 & $\% 13,3$ \\
\hline & $21 \mathrm{y} 1 \mathrm{l}+$ & 24 & $\% 22,9$ & & & & \\
\hline Toplam & & 105 & $\% 100$ & Toplam & & 105 & $\% 100$ \\
\hline
\end{tabular}

\subsection{Sanal Kaytarma ve Demografik Özellikler Arasındaki İlişki}

Araştırmaya katılan çalışanların sanal kaytarma davranışları ile demografik özellikleri arasında anlamlı bir ilişki olup olmadığını incelemek için, iki grup içeren iki grup içeren ve parametrik olmayan değişkenler için "Mann-Whitney U Testi"; ikiden fazla grup içeren ve parametrik olmayan değişkenler için "Kruskal Wallis H Testi" uygulanmıştır. Analiz sonuçları aşağıdaki tablolarda gösterilmiştir.

Tablo 4. Sanal Kaytarma Davranışları ile Cinsiyet Değişkeni Arasındaki İlişsiye Yönelik Mann Whitney U Testi Sonuçarı

\begin{tabular}{|l|l|l|l|l|l|}
\hline & N & Sira Ortalaması & Z & Sig. & Onay \\
\hline Kadın & 70 & 53,26 &,- 126 &, 900 & Ret \\
Erkek & 35 & 52,47 & & & \\
\hline
\end{tabular}

Araştırmaya katılan çalışanların sanal kaytarma davranışları ile cinsiyet arasındaki ilişkiyi ölçmek için yapılan Man Whitney U Testi sonucuna (Tablo 4) göre, cinsiyet değişkeni " $p=, 900>0,5$ " olduğundan dolayı, katılımcıların cinsiyet değişkeni ile sanal kaytarma 
davranışları arasında belirleyici bir farklılık olmadığı tespit edilmiştir, böylece $\mathrm{H}_{1}$ reddedilmiştir.

Çalışanların sanal kaytarma davranışları ile cinsiyet değişkeni arasında belirleyici bir farklılık göstermemesi; Kaplan ve Çetinkaya (2013), Örücü ve Yıldız (2014), Ünal, Tekdemir ve Yaldızbaş (2015), Arslan ve Demir (2016), Küçük ve Nur (2019) sonuçları ile benzerlik göstermektedir.

Tablo 5. Sanal Kaytarma Davranışları ile Medeni Durumları Değişkeni Arasındaki İlişkiye Yönelik Mann Whitney U Testi Sonuçları

\begin{tabular}{|l|l|l|l|l|l|}
\hline & N & Sira Ortalaması & Z & Sig. & Onay \\
\hline Evli & 78 & 54,00 &,- 573 &, 567 & Ret \\
Bekar & 27 & 50,11 & & & \\
\hline
\end{tabular}

Araştırmaya katılan çalışanların sanal kaytarma davranışları ile medeni durum değişkeni arasındaki ilişkiyi ölçmek için yapılan Man Whitney U Testi sonucuna (Tablo 5) göre, medeni durum değişkeni " $\mathrm{p}=, 567>0,5$ " olduğundan dolayı, katılımcıların medeni durum değişkeni ile sanal kaytarma davranışları arasında belirleyici bir farklılık olmadığı tespit edilmiştir, $\mathrm{H}_{3}$ reddedilmiştir.

Çalışanların sanal kaytarma davranışları ile medeni durum arasında belirleyici bir farklılık göstermemesi; Kaplan ve Çetinkaya (2013) ve Çetintürk (2020)'ün sonuçları ile benzerlik göstermektedir.

Tablo 6. Sanal Kaytarma Davranışları ile Yaş Değişkeni Arasındaki İlişkiye Yönelik Kruskal-Wallis H Testi Sonuçları

\begin{tabular}{|l|l|l|l|l|l|l|}
\hline & N & $\begin{array}{l}\text { Sıra } \\
\text { Ortalaması }\end{array}$ & Kruskal-Wallis H & df & Sig. & Onay \\
\hline 18-25 Yaş & 4 & 42,38 & & & & \\
26-33 Yaş & 25 & 49,34 & 7,245 & 4 &, 123 & Kabul \\
$34-41$ Yaş & 35 & 53,66 & & & & \\
$42-49$ Yaş & 28 & 47,75 & & & & \\
$50+$ Yaş & 13 & 72,85 & & & \\
\hline
\end{tabular}

Araştırmaya katılan çalışanların sanal kaytarma davranışları ile yaş değişkeni arasındaki ilişkiyi incelemek üzere yapılan Kruskal-Wallis H Testi sonucuna (Tablo 6) göre, yaş değişkeni " $\mathrm{p}=, 123<0,5$ " olduğundan dolayı, katılımcıların sanal kaytarma davranışları ile yaş değişkeni arasında istatiksel olarak belirleyici olduğu tespit edilmiştir. Çalışmada yer alan 50 ve üstü yaş aralığındaki katılımcıların, diğer yaş aralığındaki katılımcılara göre daha fazla; 18-25 yaş aralığında yer alan katılımcıların daha az sanal kaytarma davranışında bulunduğu sonucuna ulaşılmıştır. Böylece, $\mathrm{H}_{2}$ kabul edilmiştir.

Tablo 7. Sanal Kaytarma Davranışları ile Eğitim Değişkeni Arasındaki İlişkiye Yönelik Kruskal-Wallis H Testi Sonuçları

\begin{tabular}{|l|l|l|l|l|l|l|}
\hline & N & $\begin{array}{l}\text { Sira } \\
\text { Ortalaması }\end{array}$ & $\begin{array}{l}\text { Kruskal-Wallis } \\
\text { H }\end{array}$ & df & Sig. & Onay \\
\hline İlköğretim Mezunu & 1 & 77,50 & & & & \\
Ortaöğretim Mezunu & 14 & 53,21 & 7,505 & 4 &, 111 & Kabul \\
Ön Lisans Mezunu & 27 & 55,87 & & & & \\
Lisans Mezunu & 57 & 48,18 & & & & \\
Yüksek Lisans & 6 & 81,25 & & & \\
Mezunu & & & & & & \\
\hline
\end{tabular}

Araştırmaya katılan çalışanların sanal kaytarma davranışları ile eğitim değişkeni arasındaki ilişkiyi incelemek üzere yapılan Kruskal-Wallis H Testi sonucuna (Tablo 7) göre, eğitim 
değişkeni " $\mathrm{p}=, 111<0,5$ " olduğundan dolayı, katılımcıların sanal kaytarma davranışları ile eğitim değişkeni arasında istatiksel olarak belirleyici olduğu tespit edilmiştir. Yüksek lisans mezunu olan katılımcıların, diğer eğitim düzeyi aralığındaki katılımcılara göre daha fazla; lisans mezunu olan katılımcıların ise daha az sanal kaytarma davranışında bulunduğu sonucuna ulaş1lmıştır. Böylece, $\mathrm{H}_{4}$ kabul edilmiştir.

Tablo 8. Sanal Kaytarma Davranışları ile Görev Süresi Değişkeni Arasındaki İlişkiye Yönelik KruskalWallis H Testi Sonuçları

\begin{tabular}{|l|l|l|l|l|l|l|}
\hline & N & $\begin{array}{l}\text { Sıra } \\
\text { Ortalaması }\end{array}$ & Kruskal-Wallis H & df & Sig. & Onay \\
\hline $1-5$ Y 11 & 22 & 33,95 & & & & \\
$6-10$ Y 11 & 20 & 65,35 & 12,541 & 4 &, 014 & Kabul \\
$11-15$ Y 11 & 25 & 54,82 & & & & \\
$16-20$ Y1l & 14 & 57,86 & & & & \\
21 Y 1 ve Üzeri & 24 & 55,44 & & & \\
\hline
\end{tabular}

Araștırmaya katılan çalıșanların sanal kaytarma davranışları ile görev süresi değișkeni arasındaki ilişkiyi incelemek üzere yapılan Kruskal-Wallis H Testi sonucuna (Tablo 8) göre, görev süresi değişkeni " $\mathrm{p}=, 014<0,5$ " olduğundan dolayı, katılımcıların sanal kaytarma davranışları ile görev süresi değişkeni arasında istatiksel olarak belirleyici olduğu tespit edilmiştir. Çalışmaya katılan 1-5 yıl aralığında hizmet veren çalışanların daha az sanal kaytarma davranışında bulunduğu sonucuna ulaşılmıştır. Böylece, $\mathrm{H}_{5}$ kabul edilmiştir.

Tablo 9. Sanal Kaytarma Davranışları ile Konum Değişkeni Arasındaki İlişkiye Yönelik Kruskal-Wallis H Testi Sonuçları

\begin{tabular}{|l|l|l|l|l|l|l|}
\hline & N & $\begin{array}{l}\text { Sıra } \\
\text { Ortalaması }\end{array}$ & Kruskal-Wallis H & df & Sig. & Onay \\
\hline Hâkim-Savcı & 7 & 26,79 & 6,517 & & & \\
Müdür-Müdür Yar. & 11 & 56,73 & & 3 &, 089 & Kabul \\
Memur & 73 & 55,99 & & & & \\
Diğer & 14 & 47,61 & & & \\
\hline
\end{tabular}

Araştırmaya katılan çalışanların sanal kaytarma davranışları ile konum değişkeni arasındaki ilişkiyi incelemek üzere yapılan Kruskal-Wallis H Testi sonucuna (Tablo 9) göre, konum değişkeni " $\mathrm{p}=, 089<0,5$ " olduğundan dolayı, katılımcıların sanal kaytarma davranışları ile konum değişkeni arasında istatiksel olarak belirleyici olduğu tespit edilmiştir. Çalışmaya katılan hâkim-savcıların daha az; diğer grupların ise daha fazla sanal kaytarma davranışları gösterdiği sonucuna ulaşılmıştır. Böylece, $\mathrm{H}_{6}$ kabul edilmiştir.

\section{Sonuç}

Bu çalışma, Aydın Adliyesi'nde çalışan kamu görevlilerinin sanal kaytarma davranışları ile demografik özellikleri arasındaki ilişkinin incelenmesi amacıyla kaleme alınmıştır. Araştırmanın verileri anket yöntemi ile toplanmıştır. Araştırmanın güvenilirliğini ölçmek için Cronbach Alpha değeri hesaplanmış ve analiz sonucunda sanal kaytarma ölçeğinin güvenilir olduğu tespit edilmiştir. Sanal kaytarma ölçeğinin normal dağıllım gösterdiğini analiz etmek için Shapiro-Wilk testi yapılmıştır ve verilerin normal dağılım göstermediği gözlemlenmiştir.

Araştırmaya katılan çalışanların sanal kaytarma davranışları ile cinsiyet ve medeni durum değişkenleri arasındaki ilişkiyi incelemek için yapılan Mann-Whitney U Testi bulgularına göre, kurumda görev yapan çalışanların sanal kaytarma davranışları ile cinsiyet ve medeni durum değişkenleri arasındaki ilişkinin istatiksel olarak belirleyici farklılık olmadığı tespit edilmiştir. Bu sonuç cinsiyet değişkeni açısından, Örücü ve Yıldız (2014); Ünal, Tekdemir ve Yaldızbaş (2015); Arslan ve Demir (2016); Küçük ve Nur (2019) ile benzer sonuçlar 
gösterirken; medeni durum değişkeni açısında tam tersi sonuçlara ulaşılmıştır. Çetintürk'ün (2020) yaptığı çalışma ile aynı sonuçlara ulaştığı gözlemlenmiştir.

Araştırmaya katılan çalışanların sanal kaytarma davranışları ile yaş, eğitim, görev süresi ve konum değiş̧kenleri arasındaki ilişkiyi incelemek üzere yapılan Kruskal Wallis H Testi bulgularına göre, çalışanların sanal kaytarma davranışları ile yaş, eğitim, görev süresi ve konum değişkenleri arasındaki ilişkinin istatiksel olarak belirleyici olduğu sonucuna ulaşılmıştır. 50 yaş ve üstü katılımcıların, diğer yaş gruplarına göre daha fazla sanal kaytarma davranışında bulunduğu bulgusuna ulaşılmıştır. Yüksek lisans mezunu olan katılımcıların, diğer eğitim düzeyi aralığındaki katılımcılara göre daha fazla sanal kaytarma davranışında bulunduğu sonucuna ulaşılmıştır. 1-5 yıl aralığında hizmet veren çalışanların, diğer görev süresi aralı̆̆ında yer alan çalışanlara göre daha az sanal kaytarma davranışlarında bulunduğu tespit edilmiştir. Araştırmaya katılan hâkim-savcıların, diğer konum değișkeninde yer alan gruplara göre daha az sanal kaytarma davranıșlarında bulunduğu görülmüştür. Bu sonuç, Çetintürk (2020); Çınar ve Sıçrar (2017); eğitim değiş̧keni açısından Kaplan ve Çetinkaya (2013); görev süresi ve yaş değişkenleri bakımından Arslan ve Demir (2016); yaş, eğitim ve görev yılı değişkenlerine göre Ünal ve Tekdemir (2015) çalışmaları ile benzer sonuçlara ulaşılmıştır.

Araştırma sonucunda elde edilen bulgulara göre, günlük iş rutininde hakimlerin dava dosyalarını incelemek, duruşmaya çıkmak, keşif yapmak gibi; savcıların adli muayeneleri takip etmek, iddianame hazırlamak gibi yoğun görevlerinden dolayı sanal kaytarma davranışını daha az gösterdiği söylenebilir. Buna karşın masa başında iş yapan memurların daha fazla sanal kaytarma davranışları gösterdiği ifade edilebilir. Ayrıca görev süresi bakımından 18-25 yaş aralığındaki çalışanların işe uyum ve işi benimseme sürecinden dolayı daha az sanal kaytarma davranışında bulunduğu; buna karşın 50 ve üstü aralığındaki çalışanların fiziksel ve zihinsel tükenmişliklerinden dolayı daha fazla sanal kaytarma davranışında bulunduğu görülmektedir.

Türkiye'de, dünyadaki eğilime benzer şekilde 2000'li yıllardan sonra büyük bir aşama kaydeden teknolojik gelişmeler, özellikle kamu sektöründe çalışanların iş yükünü hafifletici etki yapmıştır. İlerleyen bilişim ve telekomünikasyon alanlarındaki gelişmeler ile bilgiye hızlı ve kolay erişim sağlamıştır. Fakat artan bu teknolojik gelişmeler, akıllı telefon ve mobil internet kullanımını arttırmıştır. Artan mobil ağ kullanımı ile, iş dışı internet kullanımı olarak tanımlanan sanal kaytarma davranışları ortaya çıkmıştır. Sanal kaytarma davranışlarının kişisel gelişim, bilgiye hızlı ulaşım, iş stresinden uzaklaşma gibi olumlu yönleri ve mesai saatleri içinde gereksiz işten kaçınma, siber saldırılar, kişisel verimliliğe etki eden olumsuz yönleri görülmektedir. Sanal kaytarma davranışlarının olumsuz yönlerinin azaltılması için kurumlar kendi bünyesinde sanal kaytarma davranışlarının neden, niçin ve kimler tarafından yapıldığını tespit etmelidir. Bunun sonucunda alınacak önlemler ve kısıtlar belirlenmelidir.

Sanal kaytarma davranışları konusunda yapılan çalışmalar incelendiğinde, kamu sektörü ve özel sektör odaklı çalışmalar yapıldığı görülmüştür. Kamu kurumu ile ilgili yapılan çalışmaların daha çok sağlık sektörü ve üniversiteler odaklı olduğu ve adliye gibi devlet kurumlarında çalışmaların az olduğu tespit edilmiştir.

Çalışmanın Aydın Merkez Adliyesini ele alması ve COVID-19 pandemi koşullarından dolayı sınırlı sayıda çalışana ulaşım sağlaması araştırmanın en önemli kısıtlarındandır. Konuyla ilgili olarak gelecekte yapılacak çalışmaların genişletilmesi için, daha fazla kişiye ulaşılarak ve nitel-nicel yöntemler bir arada kullanılarak karma bir yöntemle çalışanların sanal kaytarma davranışlarını neden tercih ettiği araştırılabilir. Ayrıca çalışmaya başka değişkenler eklenerek (örgütsel adalet, pozitif psikolojik sermaye, duygusal emek vb.) 
ölçeğin genişletilmesiyle daha kapsamlı sonuçlara ulaşılabilecek çalışmalar yapılması araştırmacılara tavsiye edilmektedir. 


\section{Kaynakça}

ARSLAN, T. E. ve DEMİR, H. (2016). Sanal Kaytarma: Bir Kamu Kurumunda Hemşireler Üzerinde Ampirik Bir Araştırma. Uluslararası Sosyal Araştırma Dergisi, 9 (43), 1626-1637.

BUYRUK AKBABA, N. A. (2019). Sanal Kaytarmanın Verimliliğe ve Maliyete Etkisi: Bir Uygulama. Verimlilik Dergisi, (3), 161-179.

ÇAVUŞOĞLU, S. ve PALAMUTÇUOĞLU, T. B. (2017). İş Tatmininin Sanal Kaytarma Üzerindeki Etkisi. Mehmet Akif Ersoy Üniversitesi Sosyal Bilimler Enstitüsü Dergisi, 9 (19), 430-444.

ÇETINTÜRK, İ. (2020). Sanal Kaytarma ve Demografik Özellikler: Beş Yıldızlı Konaklama İşletmesinde Bir Uygulama. Anadolu Üniversitesi İktisadi ve İdari Bilimler Fakültesi Dergisi, 21 (2), 35-46.

ÇINAR, O. ve SIÇRAR, H. (2019). Sanal Kaytarma ve Örgütsel Bağlılık Arasındaki İlişki: Erzurum İlinde Bir Kamu Kurumu Örneği. İş ve Hayat, 5 (10), 119-135.

https://data.tuik.gov.tr/Bulten/Index?p=Hanehalki-Bilisim-Teknolojileri-(BT)KullanimArastirmasi-2020-33679,24.08.2020

KAPLAN, M. ve ÇETINKKAYA, Ş. A. (2014). Sanal Kaytarma ve Demografik Özellikler Açısından Farklılıklar: Otel İşletmelerinde Bir Araştırma. Anatolia: Turizm Araştırmaları Dergisi, 25 (1), 26-34.

KAPLAN, M. ve ÖĞÜT, A. (2012). Algilanan Örgütsel Adalet ile Sanal Kaytarma Arasındaki İlişkinin Analizi: Hastane Çalışanları Örneği. İşletme Fakültesi Dergisi, 13 (1), 1-13.

KARATAŞ, A. ve AVCİ, B. S. (2017). Kamu Kurumlarında Sanal Kaytarma Olgusunun Değerlendirilmesi. Süleyman Demirel Üniversitesi İktisadi ve İdari Bilimler Fakültesi Dergisi, 22 (Özel Say1), 2321-2346

KARATEPE, S. ve GÜNGÖR, M. (2017). Örgütsel Özdeşleşme ve Sanal Kaytarma: Kamu Çalışanları Üzerine Bir Araştırma. ASSAM Uluslararası Hakemli Dergi, 4 (9), 80-96.

KERSE, G. ve SOYALIN, M. (2018). Kamu Kurumu Çalışanlarının Sanal Kaytarma Davranışı Adalet Algısı ve Duygusal Tükenme Düzeyiyle Açıklanabilir Mi?. İşletme Araştırmaları Dergisi, 10 (3), 210-233.

KÜÇÜK, F. ve NUR, E. (2019). Sanal Kaytarma Davranışları ile İş Verimliliği Arasındaki İlişki: Harran Üniversitesi'nde Çalışan Akademik ve İdari Personel Üzerine Bir Araştırma. Uluslararası Sosyal Araştırmalar Dergisi, 12 (66), 1102-1116.

ÖRÜCÜ, E. ve ÖZÜDOĞRU, M. (2018). Örgütsel Güven ile Sanal Kaytarma Davranışları Arasındaki İlişkinin Belirlenmesine Yönelik Bir Çalışma. Adnan Menderes Üniversitesi Sosyal Bilimler Enstitüsü Dergisi, 5 (3), 66-80.

ÖRÜCÜ, E. ve YILDIZ, H. (2014). İşyerinde Kişisel İnternet ve Teknoloji Kullanımı: Sanal Kaytarma. Ege Akademik Baklş, 14 (1), 99-114.

ÖZDEM, G. ve DEMIR, A. (2015). Okul Yöneticilerinde Sanal Kaytarma Davranışı. Mersin Üniversitesi Ë̆itim Fakültesi Dergisi, 11 (3), 1029-1042. 
ÖZKALP, E. ve YILDIZ, H. (2018). Olumlu ve Olumsuz Sanal Kaytarma Davranışlarının İşteki Stres Üzerindeki Etkisi. Endüstri İlişkileri ve İnsan Kaynakları Dergisi, 20 (1), 57-74.

ÖZÜDOĞRU, M. ve YILDIRIM, T. Y. (2020). Sanal Kaytarma ve İşgören Performansı İlişkisinde İş Stresinin Düzenleyici Etkisinin İncelenmesi: Sağlik Sektöründe Bir Araştırma. Afyon Kocatepe Üniversitesi Sosyal Bilimler Dergisi, 22 (2), 467-490.

SEÇKİN, Z. ve KERSE, G. (2017). Üniversite Öğrencilerinin Sanal Kaytarma Davranışları ve $\mathrm{Bu}$ Davranışların Çeşitli Değişkenler Açısından İncelenmesi: Ampirik Bir Araştırma. Aksaray Üniversitesi İktisadi ve İdari Bilimler Fakültesi Dergisi, 9 (1), 87108.

ÜNAL, F. Ö. ve TEKDEMIR, S. (2015). Sanal Kaytarma: Bir Kamu Kurumunda Ampirik Bir Araştırma. Süleyman Demirel Üniversitesi Iktisadi ve İdari Bilimler Fakültesi Dergisi, 20 (2), 95-118.

ÜNAL, F. Ö., TEKDEMIR, S. ve YALDIZBAŞ, S. (2015). Kamu Çalışanlarının Sanal Kaytarma Amaçları Üzerine Ampirik Bir Araştırma. Çankırı Karatekin Üniversitesi Sosyal Bilimler Enstitüsü Dergisi, 6 (2), 515-534. 